\title{
Effects of environmental temperature on oxygen diffusion capacity during post-natal development in the altricial rodent, Phyllotis darwini
}

\author{
Efectos de la temperatura ambiental sobre la capacidad de difusión de oxígeno durante el \\ desarrollo postnatal en el roedor altricial Phyllotis darwini
}

MAURICIO CANALS ${ }^{1, *}$, DANIELA P. FIGUEROA ${ }^{1}$, JESSICA P. MIRANDA $^{1}$ \& PABLO SABAT PA, $^{1,2}$

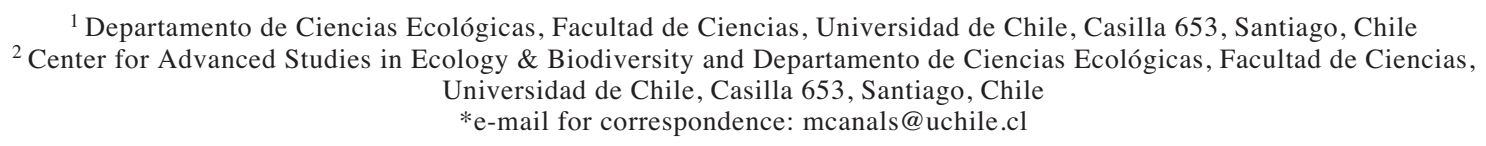

\section{ABSTRACT}

In this contribution we studied the developmental phenotypic plasticity of respiratory structures involved in the exchange of gases in an altricial rodent, the leaf-eared mouse (Phyllotis darwini). We studied morphological pulmonary parameters of warm $\left(30{ }^{\circ} \mathrm{C}\right)$ and cold acclimated animals $\left.15{ }^{\circ} \mathrm{C}\right)$ at different developmental stages. We found that acclimation treatments did not affect neither lung volume, the alveolocapillary barrier thickness nor the respiratory surface density. In consequence the oxygen diffusion capacity was not affected. Although Phyllotis darwini exhibited structural respiratory changes expected by its ontogenetic development, these structures were not affected by thermal acclimation during the post-natal development.

Key words: phenotypic plasticity, lung, altricial rodents.

\section{RESUMEN}

Estudiamos la plasticidad fenotípica del desarrollo de las estructuras respiratorias responsables del intercambio de oxígeno en el roedor altricial Phyllotis darwini. Investigamos los parámetros morfológicos del pulmón en animales aclimatados a alta temperatura (bajo requerimiento energético de termorregulación: $30{ }^{\circ} \mathrm{C}$ ) y a baja temperatura (alto requerimiento: $15^{\circ} \mathrm{C}$ ) en diferentes etapas del desarrollo. Encontramos que la temperatura ambiental no afectó el volumen pulmonar, el grosor de la barrera alvéolo-capilar ni la densidad de superficie alveolar. Y en consecuencia, tampoco la capacidad de difusión de oxígeno. Aun cuando Phyllotis darwini mostró los cambios respiratorios esperados de acuerdo a su desarrollo ontogénico, las estructuras evaluadas no fueron afectadas por la aclimatación térmica durante el desarrollo postnatal.

Palabras clave: plasticidad fenotípica, pulmones, roedores altriciales.

\section{INTRODUCTION}

Phenotypic plasticity of physiological features, or physiological flexibility, which has been visualized as an adaptive response, it is very common among vertebrate species (Pigluicci 1996, Sabat \& Bozinovic 2000, Pigluicci et al. 2006). By contrast, some morphological features appear to be more rigid and rarely are modified by the environmental cues (Sabat et al. 1998). In addition, some authors have reported the existence of phenotypic plasticity of morphology and physiology during ontogeny but absence of response when animals are adults, i.e., exhibiting an inflexible norm of reaction (Toloza \& Diamond 1990, Biviano et al. 1993, Bozinovic 1993, Zhao et al. 1996). Thus the plasticity of some morphological traits may be dependent on the ontogenetic stage at which acclimation acts (Sabat \& Bozinovic 2000), whereas for others it does not (McKechnie et al. 2007).

Accordingly, studies of phenotypic variability induced by the environment may underestimate the potential plastic response if these studies use only adult animals 
(Schlichting \& Pigliucci 1998). Several studies have demonstrated the existence of structural variation during the development of the respiratory organs in mammals (Collins et al. 1986, Winkler \& Cheville 1987, Castleman \& Lay 1990, Massaro \& Massaro 2002) and birds (Seymour et al. 2004, Runciman et al. 2005). Additionally, the structures linked with aerobic capacities have been reported to undergo dramatic ontogenetic changes, and also it appears to be more plastic in altricial than in precocial mammals during development (Tenney \& Remmers 1966, Burri 1974, Blanco et al. 1991, Burri et al. 1991, Hammond et al. 1999, 2001, Canals et al. 2000, McMutry 2002). For example, alveolar septation in precocial mammals is developed in utero, while in altricial animals the septation is post-natal (Collins et al. 1986, Winkler \& Cheville 1984, Castleman \& Lay 1990, Massaro \& Massaro 2002); alveoli of the rat (Rattus sp.) do not develop adequately until the day 7 after birth; its alveolar-capillary barrier begins to be slimed between the second and third weeks (Burri 1974, Burri et al. 1991), and ramification in the aerial pathways of this species varies during post-natal development (Canals et al. 2000).

The influence of climate on metabolic capacities of rodents has been well documented (Rosenmann \& Morrison 1974, Bozinovic \& Rosenmann 1989, Tieleman et al. 2002, 2003, Novoa et al. 2005). Nevertheless the results appear to be contradictory with regard to environmentally-induced respiratory challenges. For example, while high altitude does not seem to affect alveolar septation in Cavia porcellus (von Gesner, 1554) and Ovis aries (Linnaeus, 1758) (Tenney \& Remmers 1966), hypoxia increases alveolar size and surface in rats (Rattus sp.) (Blanco et al. 1991). Hammond et al. (1999, 2001) reported phenotypic changes in the rodent Peromyscus maniculatus (Wagner, 1845) acclimatized to high and low altitudes; these authors demonstrated that rodents acclimatized to lower oxygen partial pressures have higher hematocrit and larger lung and heart masses than those acclimatized to high oxygen partial pressures. Regarding energetic demands imposed by the style of locomotion, associations between erythrocyte size and oxygen diffusion capacity and variations in the morphology of the bronchial tree have been also reported (Canals et al. 2007, 2008).

Considering the strict association between oxygen consumption and structural oxygen diffusion capacity (oxygen conductance), and the proposition suggesting that the state of structural design is commensurate to functional needs from regulated morphogenesis (hypothesis of symmorphosis) (Weibel et al. 1991, 1992, Seymour et al. 2004, 2005, Canals et al. 2005, 2007, Runciman et al. 2005, Figueroa et al. 2007) we expected that the variables involved in the interchange and distribution of gases have the ability to change during the post-natal development according to the different metabolic demands imposed by the thermal environment. Hence, in this contribution we studied the environmentally induced developmental phenotypic plasticity in the respiratory structures involved in the exchange of gases in the leafeared mouse Phyllotis darwini (Waterhouse 1837) (Rodentia: Muridae), an altricial rodent which inhabits central Chile.

\section{MATERIAL AND METHODS}

\section{Animal models and sample size}

Fifteen adult males (mean $[ \pm$ SD $]$ body mass $=$ $54.4 \pm 17.3 \mathrm{~g})$ and 15 adult females $(37.7 \pm 7.6$ g) of $P$. darwini, a rodent dwelling in grasslands, scrub, open forest and rocky areas, were captured in Quebrada de la Plata, Maipú in central Chile, $\left(33^{\circ} 27^{\prime} \mathrm{S}, 70^{\circ} 42^{\prime} \mathrm{W}\right)$, between September and December, 2005. The animals were taken to the laboratory, where they were kept in pairs at room temperature with food (sunflower seeds and rabbit food Champion ${ }^{\circledR}$ ) and water ad lib. After mating, pregnant females were maintained in individual cages $(40 \mathrm{x} 40 \mathrm{x}$ $20 \mathrm{~cm}$ ) in thermoregulated climate chambers and randomly assigned to one of two temperature treatments. One group was maintained at low energetic requirements for thermoregulation at a constant temperature of $30 \pm 2{ }^{\circ} \mathrm{C}$ (warm acclimated group) and a second group maintained at high energetic requirements for thermoregulation below the inferior limit of thermoneutrality for this species (Bozinovic et al. 1988) at $15 \pm 2{ }^{\circ} \mathrm{C}$ (cold-acclimated group). The animals were observed daily, and were not allowed to build nest. The offspring were kept 
with the mother until the experimentation day or until weaning. After offspring were born, three unrelated individuals were selected for each environmental condition at days: one (newborn), seven, 14, 21 and 60 (adult). The entire sample collection was between December 2005 and December 2007. In the newborn group at $30^{\circ} \mathrm{C}$, four individuals were analyzed. The individuals had to be sacrificed in order to perform the structural study. Thus, except for one group with four individuals, three independent individuals were studied for each age group and environmental condition, leading to a total sample size of $n=31$.

\section{Pulmonary structure}

After the metabolic experiments, individuals were euthanized using $\mathrm{CO}_{2}$, complying with the current laws of Chile and the standards of the ethical committee of the Facultad de Ciencias, Universidad de Chile, where the experiments were performed. A small tracheotomy was performed and the lungs instilled with a $2.5 \%$ glutaraldehyde in a $0.01 \mathrm{~mol} \mathrm{~L}^{-1}$ phosphate buffer solution $(\mathrm{pH}=7.4,350 \mathrm{mOsm})$ using a plastic catheter with the reservoir located 20 $\mathrm{cm}$ above the level of the sternum. The trachea was ligated to maintain the intrapulmonary fixative volume. After $24 \mathrm{~h}$, the lungs were removed by thoracotomy and their volumes $\left(\mathrm{V}_{\mathrm{L}}\right)$ were estimated by means of a water displacement method (Scherle 1970).

Immediately following this procedure, the lungs were removed and immersed in the same fixative at $4{ }^{\circ} \mathrm{C}$ for a minimum of two hours. Next, tissues (right and left lungs) were processed for routine light microscopy (LM) and transmission electron microscopy (TEM). Briefly, two pieces of 1-2 mm thickness (one for LM and one for TEM) were obtained from each one of three zones (upper, middle and basal) in each lung. The pieces were washed with buffer and post-fixed with $1 \%$ osmium tetraoxide for $1 \mathrm{~h}$ at $4{ }^{\circ} \mathrm{C}$. For light microscopy slices were dehydrated in ascending series of ethanol and infiltrated and embedded in epoxy resin constructing cubes of $2-3 \mathrm{~mm}^{3}$, obtaining semi-thin randomly oriented sections of $1 \mu \mathrm{m}$. Tissue samples were stained with $1 \%$ toluidine blue and viewed with a microscope. For TEM, the pieces were stained with $1 \%$ osmium tetroxide, en bloc stained with $2 \%$ uranyl acetate, and dehydrated in ascending series of alcohol. Ultrathin sections of $60-90 \mathrm{~nm}$ of thickness were made, contrasted with $\mathrm{Pb}$-citrate and mounted on copper mesh grids and viewed in a JOEL/JEM 100SX transmission electron microscope. Sections were photographed and digitalized, and twelve semi-thin and twelve ultra-thin sections per individual were analyzed using Scion Image Software.

The respiratory surface density $\left(\mathrm{AS}_{\mathrm{d}}\right)$ was estimated by means of the line-intersection stereological method (Weibel 1970-1971) in the semi thin sections with light microscopy at 10X magnification:

$$
A S_{d}=\frac{2 I}{1 / 2 \cdot P_{T} \cdot Z},
$$

where $I$ is the number of intersections between line probes of length $\mathrm{Z}$ with the respiratory surface and $\mathrm{P}_{\mathrm{T}}$ is the number of testing points. The number of line segments was $1 / 2$ the number of points.

The harmonic mean thickness of the airblood barrier $\left(\tau_{\mathrm{h}}\right)$ was estimated by a stereological method in a square lattice grid as suggested by Weibel (1970-1971) and Maina (2002):

$$
\frac{1}{\tau_{h}}=\frac{3}{2} \cdot \frac{\sum_{j=1}^{m} f_{j} \cdot \frac{1}{l_{j}}}{\sum_{j=1}^{m} f_{j}},
$$

where $l_{j}$ is the mid-value of the intercept length of linear probes (on the direction of the line), $f_{j}$ the frequency of class $j$ and $m$ is the number of classes.

The thickness of the alveolo-capillary barrier, the density of the respiratory surface and the lung volume allowed the estimation of the oxygen diffusion capacity. The parenchymal lung volume was estimated as $V p$ $=0.9 \cdot V_{L}$ (Maina 2002). From these structural measurements the morphometric oxygen diffusion capacity (tissue) was estimated using:

$$
D_{t} O_{2}=\kappa \frac{A S_{d} \cdot V p}{\tau_{h}},
$$

where $\mathrm{D}_{t} \mathrm{O}_{2}$ is the oxygen diffusion capacity of the alveolo-capillary barrier (tissue) and $\kappa$ is the Krogh's diffusion coefficient $\kappa=4.1 \cdot 10^{-10}$ $\mathrm{cm}^{2} \mathrm{~s}^{-1} \mathrm{mbar}^{-1}=4.1 \cdot 10^{-12} \mathrm{~cm}^{2} \cdot \mathrm{s}^{-1} \cdot \mathrm{Pa}^{-1}(\mathrm{Gehr}$ et al. 1981). $\mathrm{AS}_{\mathrm{d}}$ is the alveolar surface density, $\mathrm{Vp}$ is the parenchymal lung volume and $\tau_{\mathrm{h}}$ is 
the harmonic mean thickness of the blood-gas barrier. The total air-erythrocyte oxygen diffusion capacity was estimated with $\mathrm{D}_{\mathrm{L}} \mathrm{O}_{2} \approx$ $\mathrm{D}_{\mathrm{t}} \mathrm{O}_{2} / 10$, a reasonable estimator derived from the ratio $\mathrm{D}_{\mathrm{L}} \mathrm{O}_{2} / \mathrm{D}_{\mathrm{t}} \mathrm{O}_{2}$. From data of Maina et al. (1991) and Maina (2002) we observed that $\mathrm{D}_{\mathrm{L}} \mathrm{O}_{2}$ is about $1 / 10$ of $\mathrm{D}_{\mathrm{t}} \mathrm{O}_{2}: \mathrm{D}_{\mathrm{L}} \mathrm{O}_{2} / \mathrm{D}_{\mathrm{t}} \mathrm{O}_{2}=0.092$ \pm 0.070 in 32 birds and $0.100 \pm 0.031$ in 10 bats (Canals et al. 2005).

The body mass response and the two structural measures $\left(\mathrm{AS}_{\mathrm{d}}\right.$ and $\left.\tau_{\mathrm{h}}\right)$ were analyzed with a two-way analysis of variance (ANOVA), using acclimation temperature and age groups as factors. The lung volume of the two groups was compared with an analysis of covariance, using the age as a co-variable.

\section{RESULTS}

\section{Lung volume}

Body mass increased at a similar rate in the two groups $\left(\mathrm{F}_{1,21}=0.176, \mathrm{P}=0.68\right)($ Table 1$)$. Because some tissues had variable degrees of lung collapse or partial rupture, we only obtained useful measurements of lung volume in 16 individuals (Table 2). Since this produced an imbalance in the model with combinations of age groups and experimental conditions, we compared lung volume between the two temperatures using an analysis of covariance, considering age as a covariate. Lung volume increased with age $\left(\mathrm{F}_{2,14}=23.74, \mathrm{P}<0.001\right)$, while mass-specific lung volume was similar among groups $\left(\mathrm{F}_{2,14}=0.347, \mathrm{P}>0.05\right)$. No differences were found neither for absolute nor for mass-specific lung volume between experimental groups $\left(\mathrm{F}_{1,14}=0.038, \mathrm{P}=0.83\right.$ and $\mathrm{F}_{1,14}=0.347, \mathrm{P}=0.79$, respectively).

\section{Blood-gas barrier}

The thickness of the alveolo-capillary barrier diminished with age in both groups $\left(\mathrm{F}_{4,21}=\right.$ $2.75, \mathrm{P}=0.055)$, from $0.434 \pm 0.046 \mu \mathrm{m}$ to $0.376 \pm 0.134 \mu \mathrm{m}$ in the groups acclimated to $30{ }^{\circ} \mathrm{C}$ and from $0.419 \pm 0.024 \mu \mathrm{m}$ to $0.322 \pm$ $0.042 \mu \mathrm{m}$ in the group acclimated to $15^{\circ} \mathrm{C}$, but there were no differences among the temperature groups $\left(\mathrm{F}_{1,21}=0.227, \mathrm{P}=0.64\right)$ (Fig. 1 and 2).

\section{TABLE 1}

Body mass (Mb) of Phyllotis darwini during the post-natal development at two environmental temperatures 15 and $30{ }^{\circ} \mathrm{C}$ Average \pm 1 standard deviation

Masa corporal (Mb) de Phyllotis darwini a través del desarrollo postnatal bajo dos temperaturas ambientales: 15 y $30{ }^{\circ} \mathrm{C}$. Promedio \pm 1 desviación estándar

\begin{tabular}{lcc}
\hline Age (days) & \multicolumn{2}{c}{ Body mass $(\mathrm{Mb})(\mathrm{g})$} \\
\cline { 2 - 3 } & \multicolumn{1}{c}{$15^{\circ} \mathrm{C}$} & $30{ }^{\circ} \mathrm{C}$ \\
\hline 1 & $3.63 \pm 0.63$ & $3.95 \pm 0.82$ \\
7 & $9.57 \pm 0.94$ & $8.23 \pm 1.04$ \\
14 & $14.63 \pm 0.91$ & $11.53 \pm 2.05$ \\
21 & $18.43 \pm 6.31$ & $16.73 \pm 1.15$ \\
60 & $38.0 \pm 8.23$ & $41.26 \pm 1.47$ \\
\hline
\end{tabular}

TABLE 2

Lung volume $\left(\mathrm{V}_{\mathrm{L}}\right)$ and mass-specific lung volume $\left(\mathrm{V}_{\mathrm{L}} / \mathrm{Mb}\right)$ of individuals of different ages of Phyllotis darwini at two environmental temperatures 15 and $30{ }^{\circ} \mathrm{C}$. Sample size in brackets

\footnotetext{
Volumen pulmonar $\left(\mathrm{V}_{\mathrm{L}}\right)$ y volumen pulmonar masa-específico $\left(\mathrm{V}_{\mathrm{L}} / \mathrm{Mb}\right)$ de individuos de diferentes edades del roedor Phyllotis darwini bajo dos temperaturas ambientales: 15 y $30{ }^{\circ} \mathrm{C}$. Número de pulmones en paréntesis
}

\begin{tabular}{|c|c|c|c|c|}
\hline \multirow[t]{2}{*}{ Age (days) } & \multicolumn{2}{|c|}{ Lung volume $\left(\mathrm{V}_{\mathrm{L}}\right)\left(\mathrm{cm}^{3}\right)$} & \multicolumn{2}{|c|}{ Mass-specific lung volume $\mathrm{V}_{\mathrm{L}} / \mathrm{Mb}\left(\mathrm{cm}^{3} \mathrm{~g}^{-1}\right)$} \\
\hline & $15^{\circ} \mathrm{C}$ & $30{ }^{\circ} \mathrm{C}$ & $15^{\circ} \mathrm{C}$ & $30{ }^{\circ} \mathrm{C}$ \\
\hline 1 & $0.128 \pm 0.030(3)$ & $0.124 \pm 0.042(3)$ & $0.037 \pm 0.016$ & $0.033 \pm 0.013$ \\
\hline 7 & $0.275 \pm 0.058(3)$ & $0.342 \pm 0.219(3)$ & $0.029 \pm 0.009$ & $0.039 \pm 0.029$ \\
\hline 14 & - & $0.330 \pm 0.067(2)$ & - & $0.027 \pm 0.010$ \\
\hline 21 & $0.600(1)$ & - & 0.025 & - \\
\hline 60 & - & $1.04(1)$ & - & 0.024 \\
\hline
\end{tabular}




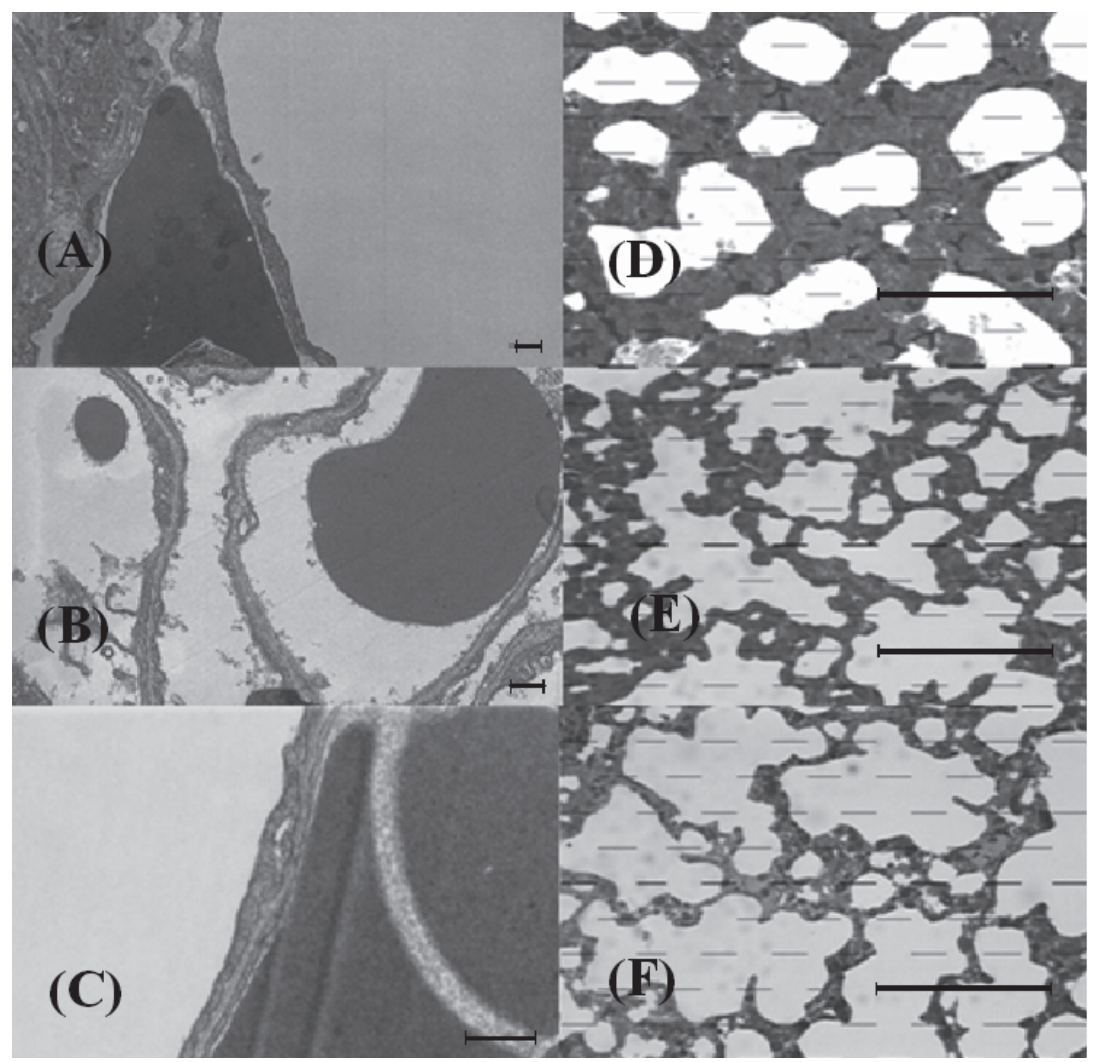

Fig. 1: Optic and transmission electronic microscopy of the lung tissue in the species Phyllotis darwini at different developmental stages: (A) one day old, 8000X, scale bar $=1 \mu \mathrm{m}$, (B) fourteen days old, $8000 \mathrm{X}$, scale bar $=1 \mu \mathrm{m},(\mathrm{C})$ sixty days old, $10000 \mathrm{X}$, scale bar $=1 \mu \mathrm{m}$, (D) one day old, $10 \mathrm{X}$, scale bar $=100 \mu \mathrm{m},(\mathrm{E})$ fourteen days old, 10X, scale bar $=100 \mu \mathrm{m},(\mathrm{F})$ sixty day old, 10X, scale bar $=100 \mu \mathrm{m}$.

Microscopía óptica y electrónica del tejido pulmonar en Phyllotis darwini en diferentes estados de desarrollo: (A) un día de edad, 8000X, barra $=1 \mu \mathrm{m},(B)$ catorce días de edad, 8000X, barra $=1 \mu \mathrm{m},(\mathrm{C})$ sesenta días de edad, 10000X, barra $=1$ $\mu \mathrm{m}$, (D) un día de edad, 10X, barra $=100 \mu \mathrm{m}$, (E) catorce días de edad, 10X, barra $=100 \mu \mathrm{m}$, (F) sesenta días de edad, $10 \mathrm{X}$, barra $=100 \mu \mathrm{m}$.

\section{Alveolar surface density}

The density of the alveolar surface increased with age in both groups $\left(\mathrm{F}_{4,21}=3.49, \mathrm{P}=\right.$ 0.024 ), from $902.75 \pm 194.62 \mathrm{~cm}^{-1}$ to $1,802.20$ $\pm 450.37 \mathrm{~cm}^{-1}$ in the group acclimated to $30{ }^{\circ} \mathrm{C}$ and from $973.70 \pm 363.21 \mathrm{~cm}^{-1}$ to $1,392.06 \pm$ $311.78 \mathrm{~cm}^{-1}$ in the group acclimated to $15^{\circ} \mathrm{C}$, with no difference between temperature groups $\left(F_{1,21}=0.323, P=0.576\right)$ (Fig. 1 and 3$)$.

\section{Oxygen diffusion capacity}

Oxygen diffusion capacity was obtained based upon the density of alveolar surface, the thickness of the alveolo-capillary barrier, and lung volumes estimations, by the Scherle method when possible and by the allometric relationship $\mathrm{V}_{\mathrm{L}}=$ $0.046 \mathrm{Mb}^{1.06}$ (body mass in $\mathrm{kg}$ and $\mathrm{V}_{\mathrm{L}}$ in $\mathrm{L}$ ) in other cases (Schmidt-Nielsen 1987). Both, the oxygen diffusion capacity and the mass specific oxygen diffusion capacity increase with age $\left(\mathrm{F}_{4,21}\right.$ $=25.22$ and $\mathrm{F}_{421}=3.62 ; \mathrm{P}<0.01$ respectively; $\mathrm{P}$ $=0.021)$; however, no difference was found between warm and cold acclimated groups $\left(\mathrm{F}_{1,21}\right.$ $=0.25$ and $F_{1,21}=0.13$ for total and mass specific oxygen diffusion capacity; $\mathrm{P}>0.62$ and 0.72 respectively) (Table 3).

\section{DISCUSSION}

We expected that the altricial rodent Phyllotis darwini, exposed to high energetic 


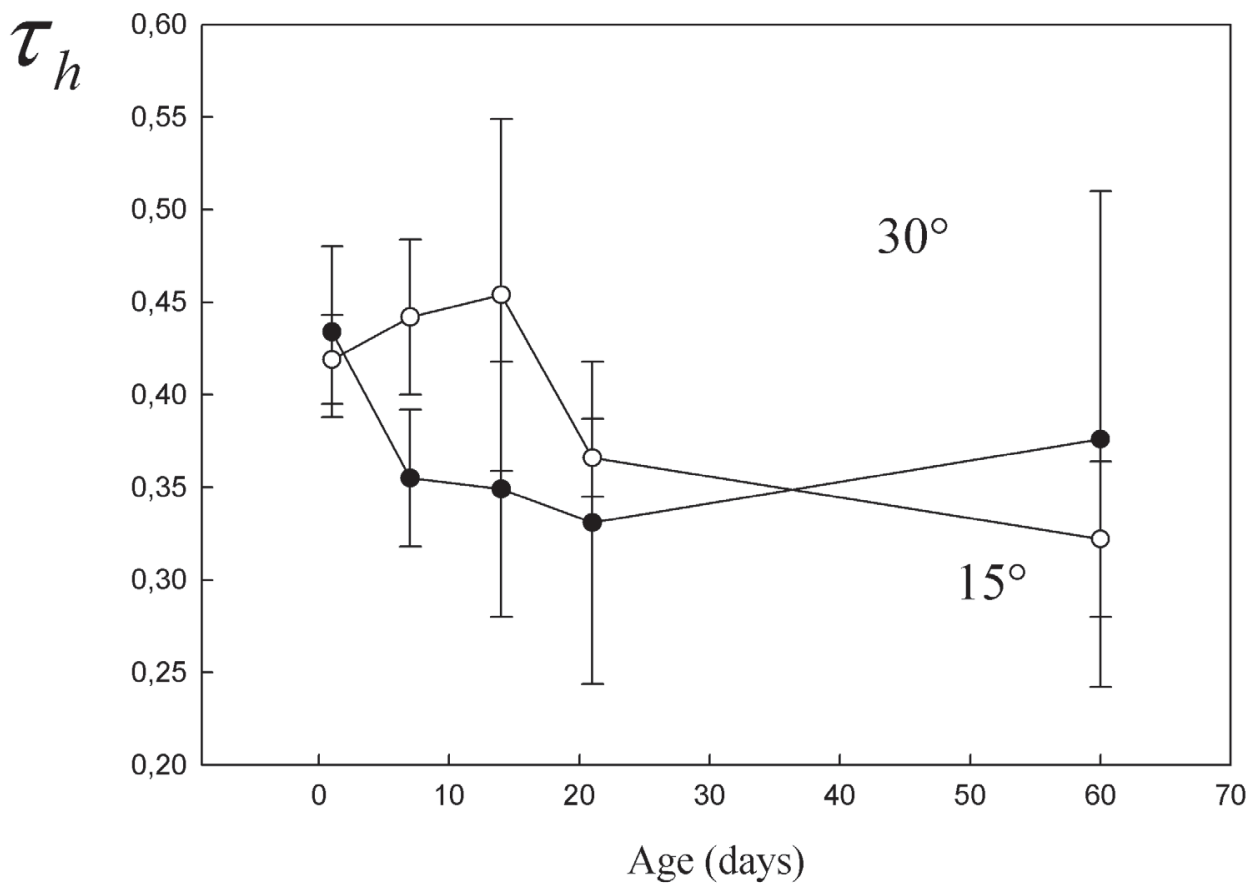

Fig. 2: Alveolo-capillary barrier thickness $\left(\tau_{\mathrm{h}}\right)$ of warm acclimated animals $\left(30^{\circ} \mathrm{C}\right.$; bold circles) and cold acclimated animals $\left(15^{\circ} \mathrm{C}\right.$; open circles) of the species Phyllotis darwini, at different ages.

Grosor de la barrera alvéolo-capilar $\left(\tau_{\mathrm{h}}\right)$ de animales de la especie Phyllotis darwini aclimatados a alta $\left(30^{\circ} \mathrm{C}\right.$; círculos negros) y baja temperatura $\left(15^{\circ} \mathrm{C}\right.$; círculos blancos $)$, a diferentes edades.

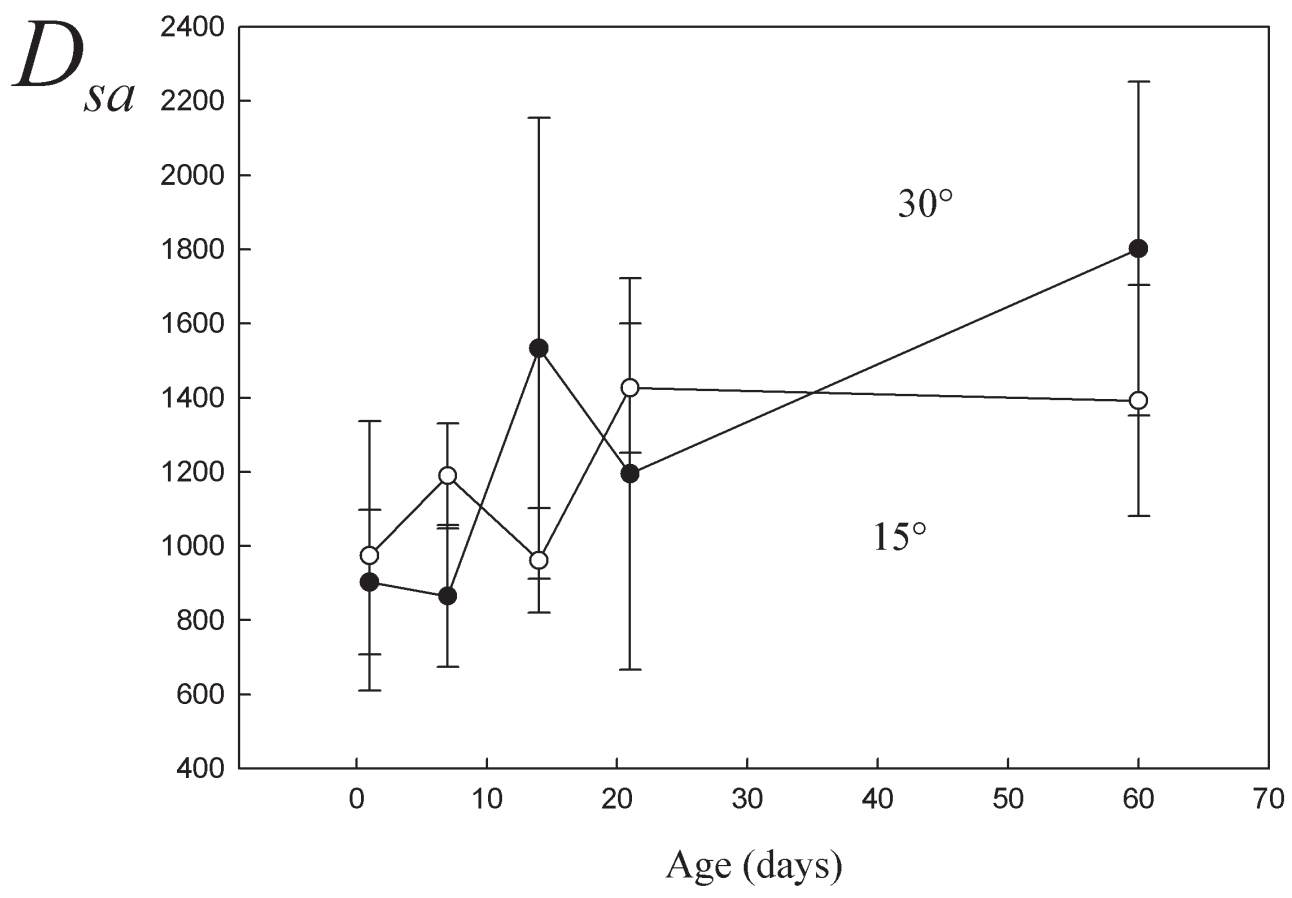

Fig. 3: Respiratory surface density $\left(\mathrm{AS}_{\mathrm{d}}\right)$ of warm acclimated animals $\left(30^{\circ} \mathrm{C}\right.$; bold circles $)$ and cold acclimated animals $\left(15^{\circ} \mathrm{C}\right.$; open circles) of the species Phyllotis darwini, at different ages.

Densidad de superficie respiratoria $\left(\mathrm{AS}_{\mathrm{d}}\right)$ de animales de la especie Phyllotis darwini aclimatados a alta $\left(30{ }^{\circ} \mathrm{C}\right.$; círculos negros) y baja temperatura $\left(15^{\circ} \mathrm{C}\right.$; círculos blancos), a diferentes edades. 


\section{TABLE 3}

Estimations of the oxygen diffusion capacity $\left(\mathrm{D}_{\mathrm{L}} \mathrm{O}_{2}\right)$ and the mass specific- $\mathrm{D}_{\mathrm{L}} \mathrm{O}_{2}$ in individuals of different ages of Phyllotis darwini at two environmental temperatures 15 and $30{ }^{\circ} \mathrm{C}$

Estimaciones de la capacidad de difusión de oxígeno total $\left(\mathrm{D}_{\mathrm{L}} \mathrm{O}_{2}\right)$ y masa-específica $\left(\mathrm{D}_{\mathrm{L}} \mathrm{O}_{2} / \mathrm{g}\right)$ en individuos de diferentes edades del roedor Phyllotis darwini bajo dos temperaturas ambientales: 15 y $30{ }^{\circ} \mathrm{C}$

\begin{tabular}{lccc}
\hline Age & $\begin{array}{c}\text { Temperature } \\
\left({ }^{\circ} \mathrm{C}\right)\end{array}$ & $\begin{array}{c}\text { Oxygen diffusion } \\
\text { capacity, } \mathrm{D}_{\mathrm{L}} \mathrm{O}_{2} \\
\left(\mathrm{mLO}_{2} \mathrm{~s}^{-1} \mathrm{~Pa}^{-1}\right) \\
\mathrm{x} 10^{-5}\end{array}$ & $\begin{array}{c}\text { Mass specific } \\
\text { oxygen diffusion } \\
\text { capacity, } \mathrm{D}_{\mathrm{L}} \mathrm{O}_{2} / \\
\mathrm{g}\left(\mathrm{mLO}_{2} \mathrm{~s}^{-1} \mathrm{~Pa}^{-1} \mathrm{~g}^{-1}\right) \\
\mathrm{x} 10^{-6}\end{array}$ \\
\hline 1 & 30 & $1.02 \pm 0.52$ & $2.66 \pm 1.48$ \\
7 & 30 & $2.35 \pm 1.74$ & $2.74 \pm 1.73$ \\
14 & 30 & $5.68 \pm 1.96$ & $5.20 \pm 2.37$ \\
21 & 30 & $6.74 \pm 0.43$ & $3.89 \pm 0.48$ \\
60 & 30 & $28.77 \pm 13.4$ & $6.99 \pm 3.29$ \\
1 & 15 & $1.15 \pm 0.71$ & $3.48 \pm 2.77$ \\
7 & 15 & $2.79 \pm 0.97$ & $3.01 \pm 1.35$ \\
14 & 15 & $4.21 \pm 1.04$ & $2.86 \pm 0.56$ \\
21 & 15 & $8.62 \pm 3.68$ & $4.68 \pm 1.24$ \\
60 & 15 & $23.01 \pm 7.4$ & $6.20 \pm 2.12$ \\
\hline
\end{tabular}

thermoregulatory requirements would reach higher aerobic capacity as adults and that such modification would be accompanied by changes in the structural lung parameters that facilitate oxygen diffusion. However, the two experimental groups exhibited similar curves of increase of body mass, development of the alveolo-capillary membrane, lung volume and alveolar surface density. In spite of the difference in the thermal environment experienced by the animals, the oxygen diffusion capacity of the alveolo-capillary membrane was similar in the two groups.

Individuals showed only the changes expected by their ontogenetic development. Values of $\mathrm{D}_{\mathrm{L}} \mathrm{O}_{2}$ increased with the age and size of animals, reaching their maximum in the adult stage in both experimental groups. This occurs mainly as a consequence of the reduction of the alveolo-capillary membrane and the increase of the alveolar surface density, since the mass-specific lung volume was practically constant. Regarding the two dominant factors $\tau_{\mathrm{h}}$ and $\mathrm{AS}_{\mathrm{d}}, \tau_{\mathrm{h}}$ reduced its thickness by $23.8 \%$, in the warm acclimated group and by $24.9 \%$ in the cold acclimated group, while the density of the alveolar surface increased by $99.6 \%$ in the warm acclimated group, and by $43.7 \%$ in the cold acclimated group. Thus, the alveolar surface density appears to be the main factor responsible for the change in $\mathrm{D}_{\mathrm{t}} \mathrm{O}_{2}$ and as a consequence in $\mathrm{D}_{\mathrm{L}} \mathrm{O}_{2}$. This is consistent with the reported pattern of postnatal development of alveolar septation in altricial mammals such as Rattus rattus (Burri 1974, Burri et al. 1991, McMutry 2002).

One possible explanation for the lack of plasticity is the existence of maternal effects that could reduce the effects of the environmental conditions. In this sense, Nespolo (2003) reported that in $P$. darwini there is a strong correlation between growth rates before weaning and adult body mass. In our case although we can not deny the existence of maternal effects, it is probable that those were randomly distributed and paired in both experimental traits. If maternal effects were different between experimental groups, differences in the structural variables at early developmental stages would be expected. However we did not find differences in pulmonary variables nor in body mass. In contrast, differences in metabolism and in the thermoregulatory capacity of newborn offspring of this species can be obtained by exposing pregnant mothers to different environmental temperatures (M. Canals unpublished results).

In our experimental setup, offspring were kept with the mother until weaning, otherwise they might have died. Nevertheless, individuals could also save energy by huddling, which allows them to reduce their overall surface structure by masking out the effect of thermal stress (Canals et al. 1989, 1997, 1998, Canals \& Bozinovic 2009). For example, in Mus musculus the energy saving during huddling (huddling effectiveness), varies depending on the developmental stage from $65.0 \%$ in juveniles to $49.8 \%$ in sub-adults and $42.4 \%$ in adults, probably as a result from variations in the capacity to change form or shape when huddling (Canals et al. 1998). However, huddling in newborn was present in both experimental conditions even though one experimental temperature was within the thermoneutral zone (Bozinovic 1988) whilst the 
other one was at least $13{ }^{\circ} \mathrm{C}$ below the minimal critical temperature of the thermoneutral zone for adults of this species. Huddling is a usual behavior in newborns at any environmental temperature because the thermoregulatory capacity is not well developed and the thermoneutral zone is displaced toward high temperatures in early stages of development (Canals et al. 1998). In more advanced developmental stages, huddling behavior, although present, may be insufficient to mask thermal stress all the time. Assessing the effect of $15{ }^{\circ} \mathrm{C}$ environmental temperature in this species (using Bozinovic et al. 1988) we estimate increments of about $36 \%$ of the energetic requirements to maintain homeothermy in always grouped individuals of this species. When individuals are not grouped this increase in the energetic requirements reaches $121 \%$. Except for newborns it is improbable that individuals were always grouped. Huddling behavior dynamics change in time, and individuals can move from one place to another. For example, in M. musculus individuals sometimes form groups and sometimes are isolated and the critical temperature below which huddling really reaches high frequency is about $15{ }^{\circ} \mathrm{C}$ (Canals $\&$ Bozinovic in press). Thus despite huddling behavior, we are confident that an environmental temperature of $15{ }^{\circ} \mathrm{C}$, is stressful for the animals.

On the other hand, lack of plasticity may be a consequence of the high Andean origin of $P$. darwini (Engel et al. 1998). Higher energetic requirements for thermoregulation maintained for long time might have conditioned at an evolutionary scale, the possession of an optimized air-blood barrier (Figueroa et al. 2007) independent of the present requirements experienced by the animals. In this study, adults of $P$. darwini showed a very thin alveolocapillary barrier: $0.322-0.367 \mu \mathrm{m}$, and also an oxygen diffusion capacity value between 3.2 and $16.3 \%$ higher than the expected value for a mammal of its body size: $6.01 \times 10^{-6} \mathrm{mLO}_{2} \mathrm{~s}^{-1}$ $\mathrm{Pa}^{-1} \mathrm{~g}^{-1}$ (Figueroa et al. 2007) and also higher than other small murids such as Mus musculus (Linnaeus, 1758), Mus wagneri (Linnaeus, 1758), Rattus rattus (Linnaeus, 1758), (Gehr et al. 1981), Abrothrix andinus (Philippi, 1858) and Abrothrix olivaceus Waterhouse, 1837 (Canals et al. 2005).
In this vein, at our knowledge there are not studies of the heritability of oxygen diffusion capacity, which could estimate the extent to which a trait has been under selection in the past (Nespolo et al. 2003). Thus how quickly those traits will respond to selection remains unknown.

\section{ACKNOWLEDGMENTS}

We thank Lafayette Eaton for their useful comments of the manuscript. Claudio Veloso and Andres Sazo provided invaluable assistance in the field and the laboratory. Funded by FONDECYT 1040649 grant to MCL.

\section{LITERATURE CITED}

BIVIANO AB, C MARTÍNEZ DEL RÍO \& DL PHILLIPS (1993) Ontogenesis of intestine morphology and intestinal disacharidases in chickens (Gallus gallus) fed contrasting purified diets. Journal of Comparative Physiology B 163: 508-510.

BLANCO LN, D MASSARO \& GD MASSARO (1991) Alveolar size, number and surface area: developmentally dependent response to $13 \% \mathrm{O}_{2}$. American Journal of Physiology 261: 370-377.

BOZINOVIC F (1993) Nutritional ecophysiology of the Andean mouse Abrothrix andinus: energy requirements, food quality and turnover time. Comparative Biochemistry and Physiology A 104: 601-604.

BOZINOVIC F, M ROSENMANN \& C VELOSO (1988) Termorregulación conductual en Phyllotis darwini (Rodentia: Cricetidae): efecto de la temperatura ambiente, uso de nidos y agrupamiento social sobre el gasto de energía. Revista Chilena de Historia Natural 61: 81-86

BOZINOVIC F \& M ROSENMANN (1989) Maximum metabolic rate of rodents: physiological and ecological consequences on distributional limits. Functional Ecology 3: 173-181.

BURRI PH (1974) The postnatal growth of the rat lung. III Morphology. Anatomical Records 178: 77-98.

BURRI PH, J DBALY \& ER WEIBEL (1991) The postnatal growth of the rat lung. I Morphometry. Anatomical Records 178: 711-730.

CANALS M \& F BOZINOVIC (in press) Thermoregulatory huddling behavior as a selforganized system. Journal of Theoretical Biology.

CANALS M, M ROSENMANN \& F BOZINOVIC (1989) Energetics and geometry of huddling in small mammals. Journal of Theoretical Biology 141: 181189.

CANALS M, M ROSENMANN \& F BOZINOVIC (1997) Geometrical aspects of the energetic effectiveness of huddling in small mammals. Acta Theriologica 42: 321-328.

CANALS M, M ROSENMANN, FF NOVOA \& F BOZINOVIC (1998) Modulating factors of the 
energetic effectiveness of huddling in small mammals. Acta Theriologica 43: 337-348.

CANALS M, R OLIVARES, F LABRA \& FF NOVOA (2000) Ontogenetic changes in the fractal geometry of the bronchial tree in Rattus norvegicus. Biological Research 33: 31-35.

CANALS M, C ATALA, R OLIVARES, F GUAJARDO, DP FIGUEROA, P SABAT \& M ROSENMANN (2005) Functional and structural optimization of the respiratory system of the bat Tadarida brasiliensis (Chiroptera, Molossidae): does airway geometry matter? Journal of Experimental Biology 208: 3987-3995.

CANALS M, C DONOSO, DP FIGUEROA \& P SABAT (2007) Pulmonary hematological parameters, energetic flight demands and their correlation with oxygen diffusion capacity in the lungs. Revista Chilena de Historia Natural 80: 275-284.

CANALS M, P SABAT \& C VELOSO (2008) The proximal airway of the bat Tadarida brasiliensis: a minimum entropy production design. Journal of Comparative Physiology B 178: 377-384.

CASTLEMAN WL \& JC LAY (1990) Morphometric and ultrastructural study of postnatal lung growth and development in calves. American Journal of Veterinary Research 51: 789-795.

COLLINS MH, J KLEINERMAN, AC MOESSINGER, AH COLLINS, LS JAMES \& WA BLANC (1986) Morphometric analysis of the growth of the normal fetal guinea pig lung. Anatomical Records 216: 381-391.

ENGEL SR, HM HOGAN, JF TAYLOR \& SK DAVIS (1998) Molecular systematics and paleobiogeography of the South American sigmodontine rodents. Molecular Biology and Evolution 15: 35-49.

FIGUEROA DP, R OLIVARES, M SALABERRY, P SABAT \& M CANALS (2007) Interplay between the morphometry of the lungs and the mode of locomotion in birds and mammals. Biological Research 40: 193-201

GEHR P, DK MWANGI, A AMMAN, GMO MALOIY, CR TAYLOR \& ER WEIBEL (1981) Design of the mammalian respiratory system. V. Scaling morphometric diffusing capacity to body mass: wild and domestic animals. Respiration Physiology 44: 61-86.

HAMMOND KA, J ROTH, DN JANES \& MR DONN (1999) Morphological and physiological responses to altitude in deer mouse Peromyscus maniculatus. Physiological and Biochemical Zoology 75: 613622.

HAMMOND KA, J SZEWCZAK \& E KROL (2001) Effects of altitude and temperature on organ phenotypic plasticity along an altitudinal gradient. Journal of Experimental Biology 204: 1991-2000.

MAINA JN, SP THOMAS \& DM DALLS (1991) A morphometric study of bats of different size: correlations between structure and function of the chiropteran lung. Philosophical Transactions of the Royal Society of London B 333: 31-50.

MAINA JN (2002) Some recent advances on the study and understanding of the functional design of the avian lung: morphological and morphometric perspectives. Biological Reviews 77: 97-152.

MASSARO D \& GD MASSARO (2002) Pre and postnatal lung development, maturation and plasticity. American Journal of Physiology 282: 345-358.

MCKECHNIE AE, K CHETTY \& BG LOVEGROVE (2007) Phenotypic flexibility in the basal metabolic rate of laughing doves: responses to short-term thermal acclimation. Journal of Experimental Biology 210: 97-106.

MCMUTRY IF (2002) Pre and postnatal lung development, maturation and plasticity. American Journal of Physiology 282: 341-344.

NESPOLO RF, LD BACIGALUPE \& F BOZINOVIC (2003) Heritability of energetics in a wild mammal, the leaf-eared mouse (Phyllotis darwini). Evolution 57: $1679-1688$.

NOVOA FF, A RIVERA-HUTINEL, M ROSENMANN \& P SABAT (2005) Intraspecific differences in metabolic rate of Chreomys olivaceus (Rodentia: Muridae): the effect of thermal acclimation in arid and mesic habitats. Revista Chilena de Historia Natural 78: 199-206.

PIGLIUCCI M (1996) How organisms repond to environmental changes: from phenotypes to molecules (and vice versa). Trends in Ecology and Evolution 11: 168-173

PIGLIUCCI M, CJ MURREN \& CD SCHLICHTING (2006) Phenotypic plasticity and evolution by genetic assimilation. Journal of Experimental Biology 209: 2362-2367.

ROSENMANN M \& PLR MORRISON (1974) Maximum oxygen consumption and heat loss facilitation in small homeotherms by He- $\mathrm{O}_{2}$. American Journal of Physiology 226: 490-495.

RUNCIMAN S, RS SEYMOUR, RV BAUDINETTE \& JT PEARSON (2005) An allometric study of lung morphology during development in the Australian pelican, Pelecanus conspicillatus, from embryo to adult. Journal of Anatomy 207: 365-380.

SABAT P \& F BOZINOVIC (2000) Digestive plasticity and the cost of acclimation to dietary chemistry in the omnivorous leaf-eared mouse Phyllotis darwini. Journal of Comparative Physiology B 170: 411-417.

SABAT P, FF NOVOA, F BOZINOVIC \& C MARTÍNEZ DEL RÍO (1998) Dietary flexibility and intestinal plasticity in birds: a field and laboratory study. Physiological Zoology 71: 226-236.

SCHERLE W (1970) A simple method for volumetry of organs in quantitative stereology. Mikroskopie 26: 57-60.

SCHLICHTING CD \& M PIGLIUCCI (1998) Phenotypic evolution: a reaction norm perspective. Sinauer Associated Inc., Sunderland, Massachusetts, USA. $415 \mathrm{pp}$

SCHMIDT-NIELSEN K (1987) Animal physiology: adaptation to environment. Third edition. Cambridge University Press, Cambridge, United Kingdom. 619 pp.

SEYMOUR RS, S RUNCIMAN, RV BAUDINETTE \& JT PEARSON (2004) Developmental allometry of pulmonary structure and function in the altricial Australian pelican Pelecanus conspicillatus. Journal of Experimental Biology 207: 2663-2669.

SEYMOUR RS, S RUNCIMAN \& RV BAUDINETTE (2005) Development of maximum metabolic rate and pulmonary diffusing capacity in the superprecocial Australian brush turkey Alectura lathami: an allometric and morphometric study. Comparative Biochemistry and Physiology, Series A. Epublication, doi:10.1016/j.cbpa.2006.03.018

TENNEY SM \& JE REMMERS (1966) Alveolar dimensions in the lungs of animals raised at high altitude. Journal of Applied Physiology 222: 15281530 .

TIELEMAN BI, JB WILLIAMS \& MB BUSCHUR (2002) Physiological adjustments to arid and mesic 
habitats in larks (Alaudidae). Physiological and Biochemical Zoology 75: 305-313

TIELEMAN BI, JB WILLIAMS \& P BLOOMER (2003) Adaptation of metabolism and evaporative water loss along an aridity gradient. Proceedings of the Royal Society of London 270: 207-214.

TOLOZA EM \& J DIAMOND (1990) Ontogenetic development of transporter regulation in bullfrog intestine. American Journal of Physiology 258: G770-G773.

TENNEY SM \& JE REMMERS (1966) Alveolar dimensions in the lungs of animals raised at high altitude. Journal of Applied Physiology 222: 15281530.

WEIBEL ER (1970-1971) Morphometric estimation of pulmonary diffusion capacity. I. Model and method. Respiration Physiology 11: 54-75.

Associate Editor: Marco Lardies

Received May 2, 2008; accepted December 17, 2008
WEIBEL ER, CR TAYLOR \& H HOPPELER (1991) The concept of symmorphosis: a testable hypothesis of structure function relationship. Proceedings of the National Academy of Sciences USA 88: $10357-$ 10361.

WEIBEL ER, CR TAYLOR \& H HOPPELER (1992) Variation in function and design: testing symmorphosis in the respiratory system. Respiration Physiology 87: 325-348.

WINKLER GC \& NF CHEVILLE (1987) The neonatal porcine lung: ultrastrucural morphology and postnatal development of the terminal airways and alveolar region. Anatomical Records 210: 303-313.

ZHAO XQ, H JORGENSEN, VM GABERT \& BO EGGUM (1996) Energy metabolism and protein balance in growing rats housed in $18{ }^{\circ} \mathrm{C}$ or $28^{\circ} \mathrm{C}$ environments and fed different levels of dietary proteins. Journal of Nutrition 126: 2036-2043. 